\title{
Synergistic Effect Between Different Milk-Derived Peptides and Proteins
}

\author{
I. López-Expósito, ${ }^{*}$ A. Pellegrini,† L. Amigo, ${ }^{*}$ and I. Recio*1 \\ *Instituto de Fermentaciones Industriales, Consejo Superior de Investigaciones Científicas, Juan de la Cierva 3, 28006 Madrid, Spain \\ †Institut für Veterinärpathologie, Universität Zürich, Winterthurstrasse 268, 8057 Zürich, Switzerland
}

\begin{abstract}
Antimicrobial peptides derived from food proteins constitute a new field in the combined use of antimicrobial agents in food. The best examples of milk-derived peptides are those constituted by bovine lactoferricin [lactoferrin $\mathrm{f}(17-41)]$ (LFcin-B) and bovine $\alpha_{\mathrm{s} 2}$-casein $\mathrm{f}(183-$ 207). The aim of this work was to study if the antimicrobial activity of a natural compound employed in food preservation, nisin, could be enhanced by combination with the aforementioned milk-derived peptides. Furthermore, the possibility of a synergistic effect between these peptides and bovine lactoferrin (LF) against Escherichia coli and Staphylococcus epidermidis was also studied. Finally, the most active combinations were assayed against the foodborne pathogens Listeria monocytogenes and Salmonella choleraesuis. Results showed a synergistic effect when LFcin-B was combined with bovine $L F$ against $E$. coli. In the same way, the combination of LFcin-B with bovine LF was synergistic against Staph. epidermidis. Bovine LF and nisin increased their antimicrobial activity when they were assayed together with bovine $\alpha_{\mathrm{s} 2}$-casein $\mathrm{f}(183-207)$. It is important to note the synergistic effect among LFcin-B and bovine LF, because both compounds might be simultaneously in the suckling gastrointestinal tract and could, therefore, have a protective effect on it. The other synergistic effect highlighted is that between $\alpha_{\mathrm{s} 2}$-casein $\mathrm{f}(183-207)$ and nisin against $L$. monocytogenes because of the ability of $L$. monocytogenes to develop resistance to nisin.
\end{abstract}

Key words: synergism, milk-derived antibacterial peptide, antibacterial milk protein

\section{INTRODUCTION}

Food preservation procedures such as pasteurization, refrigeration, canning, modified atmosphere packaging, or the incorporation of chemical preservatives in food are usually employed to prevent the growth of bacteria that may cause human disease or food spoilage. Chemi-

Received January 18, 2007.

Accepted February 20, 2008.

${ }^{1}$ Corresponding author: recio@ifi.csic.es cal preservatives such as benzoates, sorbates, nitrites, and sulfites have been used effectively, but their safety is continually under study (Knekt et al., 1999; McCann et al., 2007). The consumer demand for minimally processed foods has led to the search for biopreservatives that can be safely incorporated into various food products. Although numerous studies have shown the effectiveness of biopreservatives against microorganisms (Altieri et al., 2005; Schnurer and Magnusson, 2005), some of them have a limited spectrum of activity, high application cost, or negative effect on the organoleptic quality of foods (Dufour et al., 2003). These limitations can, to an extent, be overcome by combinations of different antimicrobial agents (Zapico et al., 1998; Branen and Davidson, 2004), combinations of antimicrobials with chelating agents (Stevens et al., 1991), or by the use of antimicrobials together with preservative treatments such as high hydrostatic pressure, low $\mathrm{pH}$, or freeze-thaw cycles (Roberts and Hoover, 1996; García-Graells et al., 2000; Cressy et al., 2003).

Nisin is a bacteriocin produced by Lactocococcus lactis spp. lactis that is primarily active against gram-positive bacteria, and it has found practical application as a food preservative in several food products (Delves-Broughton et al., 1996). The practical application of nisin, however, is limited because of its low stability, reduced activity at high $\mathrm{pH}$, and poor efficacy in certain food matrices (Pol and Smid, 2000).

Lactoferrin (LF) is a key element of the innate host defense system, and, as such, it has crucial antimicrobial activities against a broad range of pathogens. In the case of bacteria, LF affects many gram-positive and gramnegative pathogens (Valenti and Antonini, 2005). In contrast, it seems to promote the growth of beneficial bacteria such as Lactobacillus and bifidobacteria (Sherman et al., 2004). The large-scale preparation of LF from cheese whey or skim milk makes it available for human and animal health purposes and commercial applications. Lactoferrin is also used in food preservation by limiting the growth of microbes. For example, incorporation of bovine LF into edible films has a great potential to enhance the safety of foods, or it can also be directly used as a spray applied to beef carcases (Taylor et al., 2004). 
Antimicrobial peptides derived from food proteins constitute a new field in the use of antimicrobial agents in food. Some of them have shown potent antimicrobial activity and a broad spectrum against gram-positive and gram-negative microorganisms. Antimicrobial peptides have been isolated from various food proteins, but the greatest number described to date are from milk (LópezExpósito and Recio, 2006) or from chicken egg white (Ibrahim et al., 2000; Pellegrini et al., 2004). One of the most potent milk-derived antimicrobial peptides described so far corresponds to a fragment of the whey protein LF, named lactoferricin (Bellamy et al., 1992), which possesses an antimicrobial potency against a wide range of microorganisms, which is 10 -fold greater than that of the parent protein. Another peptide with a strong antimicrobial activity against gram-positive and gramnegative microorganisms is that corresponding to the bovine $\alpha_{\mathrm{s} 2}$-casein $\mathrm{f}(183-207)$. This fragment was obtained by hydrolysis of the bovine $\alpha_{\mathrm{s} 2}$-casein with pepsin (Recio and Visser, 1999b). Although only few works deal with the synergistic effect of $L F$ with other antimicrobial compounds such as monolaurin, lysozyme, or EDTA (Ellison and Giehl, 1991; Branen and Davidson, 2004), to our knowledge, no synergism has been described among milk-derived peptides and nisin and LF.

The aim of this work was to study whether the peptides $\alpha_{\mathrm{s} 2}$-casein $\mathrm{f}(183-207)$ and bovine lactoferricin (LFcin-B) can exert a synergistic effect in combination with other food proteins and peptides toward selected foodborne pathogens and spoilage bacteria. We intended to evaluate if these 2 antibacterial peptides were able to destabilize the outer membrane of gram-negative microorganisms, to facilitate access of antimicrobial agents with a limited spectrum of activity against gram-negative microorganisms such as LF and nisin.

\section{MATERIALS AND METHODS}

\section{Bacterial Strains and Growth Media}

Escherichia coli ATCC 25922 was from the American Type Culture Collection (Rockville, MD), and Listeria monocytogenes CECT 934, Staphylococcus epidermidis CECT 231, and Salmonella choleraesuis ssp. choleraesuis CECT 4594 were from the Spanish Type Culture Collection (Colección Española de Cultivos Tipo, Valencia, Spain). Tryptic soy broth (TSB), tryptic soy agar (TSA), brain-heart infusion agar (BHIA), and brainheart infusion (BHI) were from Scharlau (Barcelona, Spain). Unless otherwise stated, all other chemicals were of the highest grade commercially available.

\section{Chemicals}

Bovine LF was kindly donated by Domo Food Ingredients (Beilen, the Netherlands). Iron content of the LF preparation was determined by inductively coupled plasma-optical emission spectrometry (Larrea et al., 1997). Nisin (2.5\% nisin) was purchased from Sigma (St. Louis, MO).

\section{$\alpha_{s 2}$-Casein $f(183-207)$ and LFcin-B Preparation}

Bovine $\alpha_{\mathrm{s} 2}$-casein f(183-207) was prepared by conventional fluorenyl-methoxy-carbonyl solid-phase synthesis method with a 431A peptide synthesizer (Applied Biosystems Inc., Überlingen, Germany) and purified after synthesis by semipreparative reversed-phase HPLC (RPHPLC) with the conditions described previously by López-Expósito et al. (2006a).

The LFcin-B was prepared as described previously by Recio and Visser (1999a). Briefly, an LF hydrolysate (5\% $\mathrm{wt} / \mathrm{vol}$ ) was prepared in acidified water $(\mathrm{pH} 3.0)$ with $3 \%$ (wt/wt) of porcine pepsin A (EC 3.4.23.1, $445 \mathrm{U} / \mathrm{mg}$ of solid, Sigma) for $4 \mathrm{~h}$ at $37^{\circ} \mathrm{C}$. The reaction was terminated by heating at $80^{\circ} \mathrm{C}$ for $15 \mathrm{~min}$, and the $\mathrm{pH}$ was adjusted to 7.0 by the addition of $1 M \mathrm{NaOH}$. The supernatant obtained after centrifugation $(16,000 \times g$ for 15 min) was injected onto a column $(150 \times 26 \mathrm{~mm}$ i.d. $)$ of SP-Sepharose Fast Flow resin (Pharmacia LKB Biotechnology, Uppsala, Sweden) equilibrated at $4^{\circ} \mathrm{C}$ with ammonium hydrogen carbonate buffer acidified with formic acid to $\mathrm{pH}$ 7.0. Peptides were eluted with a flow rate of $5 \mathrm{~mL} / \mathrm{min}$ with a gradient going from 0 to $100 \%$ in 70 min of $5 M$ ammonia solution. Finally, the column was eluted with $2 M \mathrm{NaCl}$, and this fraction containing LFcin-B was desalted by a semipreparative RP-HPLC step. The purity of the LFcin-B obtained was evaluated by RP-HPLC-MS as described previously (LópezExpósito et al., 2006b).

\section{Antimicrobial Activity}

Antimicrobial activity was determined using CryoTubes Vials (Nunc, Roskilde, Denmark). Single colonies of bacteria grown on TSA plates (E. coli, S. choleraesuis, and Staph. epidermidis) or BHIA plates (L. monocytogenes) were inoculated with $10 \mathrm{~mL}$ of TSB or BHI and grown overnight at $37^{\circ} \mathrm{C}$. A total of $300 \mu \mathrm{L}$ of bacterial suspension was diluted 1/50 with TSB or BHI. Bacteria were grown at $37^{\circ} \mathrm{C}$, and logarithmic phase organisms were harvested at a density of 1 to $4 \times 10^{8} \mathrm{cfu} / \mathrm{mL}$. The culture was then centrifuged at $2,000 \times g$ for $10 \mathrm{~min}$. Bacteria were washed twice with $10 \mathrm{~m} M$ Na-phosphate buffer, $\mathrm{pH}$ 7.4, and adjusted to $10^{5} \mathrm{cfu} / \mathrm{mL}$ approximately. A total of $50 \mu \mathrm{L}$ of the bacterial suspension was mixed with $50 \mu \mathrm{L}$ of the antimicrobial sample to be investigated together with $100 \mu \mathrm{L}$ of $2 \%$ TSB or BHI in $10 \mathrm{mM}$ phosphate buffer, $\mathrm{pH} 7.4$, and with $800 \mu \mathrm{L}$ of 10 $\mathrm{m} M$ phosphate buffer, $\mathrm{pH}$ 7.4. The mixture was incu- 
Table 1. Antibacterial activity expressed as the concentration $(\mu M)$ of antimicrobial agent that gave a log $\left(\mathrm{N}_{0} / \mathrm{N}_{\mathrm{f}}\right)$ value between 0.25 and 0.5 against different gram-negative (Escherichia coli, Salmonella choleraesuis) and gram-positive (Staphylococcus epidermidis, Listeria monocytogenes) microorganisms for each antimicrobial agent evaluated ${ }^{1}$

\begin{tabular}{llcccc}
\hline & \multicolumn{2}{c}{ Gram-negative } & & \multicolumn{2}{c}{ Gram-positive } \\
\cline { 2 - 3 } \cline { 5 - 6 } Antimicrobial & E. coli & S. choleraesuis & & Staph. epidermidis & L. monocytogenes \\
\hline LF & 0.075 & 1.25 & & 2.500 & 0.25 \\
Nisin & 0.500 & 5.00 & & 0.050 & 0.25 \\
f(183-207) & 1.250 & 0.5 & & 2.500 & 0.05 \\
LFcin-B & 0.0125 & ND $^{2}$ & & 0.050 & ND \\
\hline
\end{tabular}

${ }^{1}$ Molecular masses considered were 77,000 for lactoferrin (LF), 3,475 for nisin, 3,115 for $\alpha_{\mathrm{s} 2}$-casein $\mathrm{f}(183-$ 207), and 3,125 for bovine lactoferricin (LFcin-B).

${ }^{2} \mathrm{ND}=$ not determined.

bated at $37^{\circ} \mathrm{C}$ for $2 \mathrm{~h}$ with agitation and then plated on TSA or BHIA plates. The plates were incubated at $37^{\circ} \mathrm{C}$ (E. coli, S. choleraesuis, Staph. epidermidis) or $30^{\circ} \mathrm{C}(\mathrm{L}$. monocytogenes) for $24 \mathrm{~h}$ before the colonies were counted. The assays were conducted in triplicate. The antimicrobial activity was expressed as the concentration of antimicrobial agent that gave a $\log \left(\mathrm{N}_{0} / \mathrm{N}_{\mathrm{f}}\right)$ value between 0.25 and 0.5 .

\section{Evaluation of Synergy}

To determine antimicrobial interactions, a synergy index was defined based on fractional inhibitory concentration-index (FIC index) described previously by Davidson and Parish (1989). The synergy index of an individual antimicrobial compound is the ratio of the concentration of the antimicrobial compound in an inhibitory combination with a second compound to the concentration of the antimicrobial by itself as follows:

$$
\text { Index } \mathrm{A}_{\mathrm{A}}=(\text { activity of } \mathrm{A} \text { with } \mathrm{B}) / \text { activity of } \mathrm{A} \text {. }
$$

The synergy index was calculated as follows with the indices for the individual antimicrobials: synergy index = Index $x_{\mathrm{A}}+$ Index $_{\mathrm{B}}$. If the synergy index is $<1$, the interaction is considered to be synergistic; if the synergy index = 1 , the interaction is additive; and a synergy index $>1$ represents antagonism between 2 substances.

\section{RESULTS AND DISCUSSION}

\section{Determination of the Antibacterial Activity}

The antibacterial activity of the protein and peptides under investigation was determined against 2 gram-negative and 2 gram-positive bacterial strains, and the results are shown in Table 1. The lantibiotic nisin was active against both gram-negative and gram-positive bacteria, although against the gram-negative microorganisms, it showed notably lower activity than against the gram-positive ones. Nisin is an antimicrobial compound with a spectrum limited essentially to gram-positive microorganisms. Our results showed that nisin could also exert certain antimicrobial activity against gram-negative bacteria, confirming the results reported by Kuwano et al. (2005). The disparities found by different authors are probably due to the conditions of the antibacterial assay. In any case, the results reported in Table 1 show that to reveal some appreciable antibacterial activity against gram-negative bacteria, nisin must be assayed at least at a concentration 10 times higher than against gram-positive bacteria.

The LF was active against both gram-negative and gram-positive bacteria. The LF preparation used in this study contained $198 \pm 5 \mu \mathrm{g}$ of iron/g of dry weight as determined by elemental analysis (i.e., approximately $13.6 \%$ saturation, considering 2 metal binding sites per $77,000 \mathrm{Da})$. The antibacterial activity values ranged from $0.075 \mu M$ against $E$. coli to $2.5 \mu M$ against Staph. epidermidis. In fact, regarding gram-negative bacteria, LF was strongly active against $E$. coli and to a lesser extent against $S$. choleraesuis. Among gram-positive bacteria, $L$. monocytogenes was highly sensitive to LF, whereas Staph. epidermidis was only weakly affected by the action of this protein. Thus, the differences observed cannot be easily explained in terms of a different composition of the bacterial membrane. These results are in agreement with previous studies with human LF in which nonenteropathogenic strains of $E$. coli were classified as LF-sensitive strains and Staph. epidermidis was relatively resistant to the effect of apo-LF (Arnold et al., 1980). The peptide fragment of LF, LFcin-B, was active against both gram-negative and gram-positive bacteria. Its antibacterial activity was stronger than that of its parent protein, confirming the results reported by other authors (Bellamy et al., 1992). As shown in Table 1, similar activity was previously found for Lfcin-B against E. coli and Staph. epidermidis (Jones et al., 1994).

The peptide $\mathrm{f}(183-207)$ derived from $\alpha_{\mathrm{s} 2}$-casein was active against both gram-negative and gram-positive 
Table 2. Antibacterial activity expressed as the concentration $(\mu M)$ of antimicrobial agent that gave a log $\left(\mathrm{N}_{0} / \mathrm{N}_{\mathrm{f}}\right)$ value between 0.25 and 0.5 and synergy indexes (index) for each combination assayed against Escherichia coli ATCC 25922 and Staphylococcus epidermidis ${ }^{1}$

\begin{tabular}{|c|c|c|c|c|c|c|}
\hline \multirow[b]{2}{*}{ Antimicrobial } & \multicolumn{3}{|c|}{ E. coli } & \multicolumn{3}{|c|}{ Staph. epidermidis } \\
\hline & Activity & Index & Effect & Activity & Index & Effect \\
\hline \multicolumn{7}{|l|}{ LFcin-B with } \\
\hline LF & 0.0075 & 0.68 & Synergism & 0.0025 & 0.51 & Synergism \\
\hline Nisin & 0.0500 & 4.02 & Antagonism & 0.0250 & 1.00 & Additive \\
\hline \multicolumn{7}{|l|}{$\alpha_{\mathrm{s} 2}$-Casein $\mathrm{f}(183-207)$ with } \\
\hline LF & 0.025 & 0.35 & Synergism & 0.0250 & 0.02 & Synergism \\
\hline Nisin & 2.500 & 7.00 & Antagonism & 0.0050 & 0.10 & Synergism \\
\hline$\alpha_{\mathrm{s} 2}$-Casein $\mathrm{f}(183-207)$ with & \multicolumn{3}{|c|}{ Salmonella choleraesuis } & \multicolumn{3}{|c|}{ Listeria monocytogenes } \\
\hline $\mathrm{LF}$ & 2.5 & 1.75 & Antagonism & 0.0025 & 0.60 & Synergism \\
\hline Nisin & 0.0625 & 5.50 & Antagonism & 0.0025 & 0.60 & Synergism \\
\hline
\end{tabular}

${ }^{1}$ Combinations of $\alpha_{\mathrm{s} 2}$-casein $\mathrm{f}(183-207)$ with lactoferrin (LF) and nisin were also assayed against Salmonella choleraesuis and Listeria monocytogenes. LFcin-B = bovine lactoferricin.

bacteria. However, similarly to LF, notable differences were observed in the bactericidal activity against the strains investigated. Listeria monocytogenes was the strain most sensitive to the action of $\mathrm{f}(183-207)$, whereas Staph. epidermidis was the least.

\section{Interactions Between LFcin-B and Other Antimicrobial Compounds}

To investigate a possible synergistic effect between LFcin-B and LF or nisin against E. coli and Staph. epidermidis, synergy indices were calculated. Results are shown in Table 2. From the results obtained, it must be highlighted that LF and the LF-derived peptide, LFcinB, acted synergistically against $E$. coli and Staph. epidermidis. The LFcin-B and LF displayed against $E$. coli activity values of 0.0125 and $0.075 \mu M$, respectively, whereas the activity value decreased to $0.0075 \mu M$ when they were assayed together. The synergy index determined for the combination LF and LFcin-B against $E$. coli and Staph. epidermidis was 0.68 and 0.51, respectively (Table 2). The LF and LFcin-B used in this study were of bovine milk, but if this synergism could also be demonstrated with LFcin and LF from human origin, it could have physiological implications. It has been demonstrated by mass spectrometry that significant amounts of fragments that contain LFcin-B are produced in human stomach following ingestion of LF, and therefore, functional quantities of human LFcin might be generated in the human stomach (Kuwata et al., 1998a). Additionally, LFcin has also been detected in the gastrointestinal tract of adult mice (Kuwata et al., 1998b). In the same way, it was demonstrated that a portion of ingested LF is incompletely hydrolyzed (Spik et al., 1982), and the concentration of LF in human milk is approximately $2 \mathrm{~g} / \mathrm{L}$ in mature milk (Lönnerdal, 2003) and $7 \mathrm{~g} / \mathrm{L}$ in human colostrum (Ward and Conneely, 2004). It is, therefore, likely that LF and LFcin coexist in the gastrointestinal tract of the breast-fed infants, and these compounds could act synergistically, increasing the defenses of the host against invading microorganisms.

When LFcin-B was combined with nisin, an antagonistic effect was found against $E$. coli (FIC index of 4.02), whereas the synergy index achieved against Staph. epidermidis revealed an additive interaction (synergy index of 1.0). This antagonistic effect was also previously reported when nisin was combined with reuterin against gram-negative microorganisms (Arqués et al., 2004a).

\section{Interactions Between Bovine $\alpha_{s 2}$-Casein f(183-207) and Other Antimicrobial Compounds}

As shown in Table 2, the synergy indices obtained with the $\alpha_{\mathrm{s} 2}$-casein peptide combined with $\mathrm{LF}$ and nisin revealed a synergistic effect against Staph. Epidermidis. Particularly efficient were the combinations of the $\alpha_{\mathrm{s} 2^{-}}$ casein peptide with LF and nisin against Staph. epidermidis, with synergy values of 0.02 and 0.1 , respectively. These low indices indicate a strong synergism of these 2 combinations. As can be observed from Figure 1, when both substances were tested alone, concentrations of 10 $\mu M$ of LF and $5 \mu M$ of the $\alpha_{\mathrm{s} 2}$-casein peptide were required to reach the maximum growth inhibition. When the combination of $\mathrm{LF}$ and the $\alpha_{\mathrm{s} 2}$-casein peptide was assayed, a concentration of $2.5 \mu M$ of each compound was enough to obtain the same effect. If the $\alpha_{\mathrm{s} 2}$-casein peptide could be generated upon enzymatic hydrolysis in the suckling gastrointestinal tract, this synergism might also have a physiological meaning, because both compounds could coexist in the gastrointestinal tract of a breast-fed infant. On the other hand, the synergy 


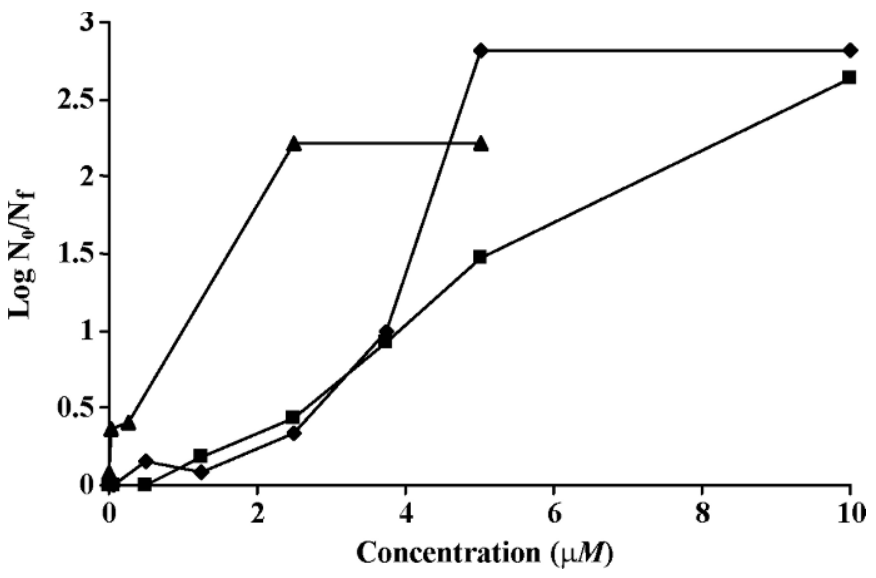

Figure 1. Antibacterial activity at different concentrations of lactoferrin (ם), $\alpha_{\mathrm{s} 2}$-casein $\mathrm{f}(183-207)(\diamond)$, and lactoferrin $+\alpha_{\mathrm{s} 2}$-casein $\mathrm{f}(183-207)(\mathbf{\Delta})$ against Staphylococcus epidermidis CECT 231 growth in tryptic soy broth. Antibacterial activity was calculated as $\log \mathrm{N}_{0} /$ $\mathrm{N}_{\mathrm{f}}$, where $\mathrm{N}_{0}$ refers to the control number of colonies without antibacterial material $\left(10^{3} \mathrm{cfu} / \mathrm{mL}\right)$ and $\mathrm{N}_{\mathrm{f}}$ refers to the number of colonies containing antibacterial compounds after an incubation period of 2 $\mathrm{h}$ at $37^{\circ} \mathrm{C}$.

between $\alpha_{\mathrm{s} 2}$-casein $\mathrm{f}(183-207)$ and nisin could find some application in the food industry, in which nisin is already used as a food preservative. Other authors have obtained a synergistic interaction by combining nisin with monolaurin (Mansour and Millière, 2001), garlic extract (Singh et al., 2001), lactoperoxidase system (Zapico, et al., 1998), or reuterin (Arqués et al., 2004b), but to date, the interaction of nisin with other milk proteins and peptides has not been attempted. Against E. coli, only the combination of the casein-derived peptide with LF demonstrated a synergistic interaction, whereas combination with nisin had an antagonistic effect. It had been previously reported that LF in combination with monolaurin inhibited growth of $E$. coli $\mathrm{O} 157: \mathrm{H} 7$ but not $E$. coli O104:H21 (Branen and Davidson, 2004), and therefore, this synergistic behavior should be confirmed with other E. coli strains.

\section{Bovine $\alpha_{s 2^{-}}$Casein $f(183-207)$ Interactions Against Foodborne Pathogens}

Combinations with synergy indices lower than 0.5 were also assayed against the foodborne pathogens $S$. choleraesuis and L. monocytogenes. The results obtained for the combinations of $\alpha_{\mathrm{s} 2}$-casein $\mathrm{f}(183-207)$ with LF and nisin are shown in Table 2 . These 2 combinations were synergistic against $L$. monocytogenes but had an antagonistic effect when tested against $E$. coli. Of special interest was the combination of the peptide from $\alpha_{\mathrm{s} 2^{-}}$ casein with nisin because of the ability of $L$. monocytogenes to develop resistance to nisin (Davies and Adams,
1994). Probably, the peptide $\alpha_{\mathrm{s} 2}$-casein f(183-207) could destabilize the bacterial membrane, making this microorganism more susceptible to the action of nisin. Therefore, as indicated above, the combination of $\alpha_{\mathrm{s} 2}$-casein $f(183-207)$ and nisin could be of use in the food industry as a food preservative.

In relation to $S$. choleraesuis, none of the combinations assayed were synergistic against this bacterium. The synergy index was 1.75 for the combination with LF and 5.50 for the combination with nisin (Table 2). The reason why these 2 combinations, casein-derived peptide with LF or nisin, were synergistic against the gram-positive bacteria (Staph. epidermidis and L. monocytogenes) but not against gram-negative bacteria $(E$. coli and $S$. choleraesuis) is not clear. It may be due to the more complex membrane structure of gram-negative bacteria. However, combinations of LF with LFcin-B or with the casein-derived peptide exerted a synergistic effect against $E$. coli. It has been postulated that differences in the antibacterial action of EDTA-nisin combinations against different gram-negative bacteria could be attributed to differences in the outer membrane or LPS structure, which may affect the amount of LPS released from the outer membrane and the resulting increase in permeability (Branen and Davidson, 2004).

\section{CONCLUSIONS}

The antimicrobial activity of LF and nisin can be enhanced by simultaneous addition of the peptides LFcinB and $\alpha_{\mathrm{s} 2}$-casein $\mathrm{f}(183-207)$. More specifically, these 2 peptides have been demonstrated to act synergistically or additively with LF and nisin against the gram-positive microorganism Staph. epidermidis. However, against gram-negative $E$. coli, only the combination of these 2 peptides with $\mathrm{LF}$ have proved to be more effective at inhibiting bacterial growth than either agent used alone. Peptide $\alpha_{\mathrm{s} 2}$-casein $\mathrm{f}(183-207)$ synergistically enhanced the activity of nisin and LF against $L$. monocytogenes. Some of these combinations, such as LF with LFcin-B or LF with $\alpha_{\mathrm{s} 2}$-casein $\mathrm{f}(183-207)$, may be relevant for the host defense properties of LF. The results obtained in this work further highlight the potential of using nisin in combination with $\alpha_{\mathrm{s} 2}$-casein $\mathrm{f}(183-207)$ to improve its effectiveness at inhibiting L. monocytogenes. Although results obtained in growth media cannot be directly extrapolated to food matrices, this combination may, therefore, be promising for use in food preservation.

\section{ACKNOWLEDGMENTS}

This work has received financial support from projects AGL2005-03381 and CM-S0505-AGR-0153. I. LópezExpósito was the recipient of a fellowship from the Minis- 
terio de Ciencia y Tecnología, Spain. The authors would like to thank Ana Molinete for her technical assistance.

\section{REFERENCES}

Altieri, C., B. Speranza, M. A. Del Nobile, and M. Sinigaglia. 2005. Suitability of bifidobacteria and thymol as biopreservatives in extending the shelf life of fresh packed plaice fillets. J. Appl. Microbiol. 99:1294-1302.

Arnold, R. R., M. Brewer, and J. J. Gauthier. 1980. Bactericididal activity of human lactoferrin: Sensitivity of a variety of microorganims. Infect. Immun. 28:893-898.

Arqués, J. L., J. Fernández, P. Gaya, M. Nuñez, E. Rodríguez, and M. Medina. 2004b. Antimicrobial activity of reuterin in combination with nisin against food-borne pathogens. Int. J. Food Microbiol. 95:225-229.

Arqués, J. L., M. Nuñez, M. Medina, and E. Rodríguez. 2004a. Synergistic effect of reuterin in combination with nisin on Staphylococcus aureus in milk. Milchwissenschaft 59:373-375.

Bellamy, W., M. Takase, H. Wakabayahi, K. Kawase, and M. Tomita. 1992. Antibacterial spectrum of lactoferricin B, a potent bactericidal peptide derived from the $\mathrm{N}$-terminal region of bovine lactoferrin. J. Appl. Bacteriol. 73:472-479.

Branen, J. K., and P. M. Davidson. 2004. Enhancement of nisin, lysozyme, and monolaurin antimicrobial activities by ethylenediaminetetraacetic acid and lactoferrin. Int. J. Food Microbiol. 90:63-74.

Cressy, H. K., A. R. Jerret, C. M. Osborne, and P. J. Bremer. 2003. A novel method for the reduction of cell numbers of Listeria monocytogenes by freezing in combination with an essential oil in bacteriological media. J. Food Prot. 66:390-395.

Davidson, P. M., and M. E. Parish. 1989. Methods for testing the efficacy of food antimicrobials. Food Technol. 43:148-155.

Davies, E. A., and M. R. Adams. 1994. Resistance of Listeria monocytogenes to the bacteriocin nisin. Int. J. Food Microbiol. 21:341-347.

Delves-Broughton, J., J. P. Blackburn, R. J. Evans, and J. Hugenholtz. 1996. Applications of the bacteriocin, nisin. Antonie Van Leeuwenhoek 69:193-202.

Dufour, M., R. S. Simmonds, and P. J. Bremer. 2003. Development of a method to quantify in vitro the synergistic activity of "natural" antimicrobials. Int. J. Food Microbiol. 85:249-258.

Ellison, R. T., and T. Giehl. 1991. Killing of gram-negative bacteria by lactoferrin and lysozyme. J. Clin. Invest. 88:1080-1091.

García-Graells, C., C. Valckx, and C. W. Michiels. 2000. Inactivation of Escherichia coli and Listeria innocua in milk by combined treatment of high hydrostatic pressure and the lactoperoxidase system. Appl. Environ. Microbiol. 66:4173-4179.

Ibrahim, H. R., Y. Sugimoto, and T. Aoki. 2000. Ovotransferrin antimicrobial peptide (OTAP-92) kills bacteria through a membrane damage mechanism. Biochim. Biophys. Acta 1523:196-205.

Jones, E. M., A. Smart, G. Bloomberg, L. Burgess, and M. R. Millar. 1994. Lactoferricin, a new antimicrobial peptide. J. Appl. Bacteriol. 77:208-214.

Knekt, P., R. Jarvinen, J. Dich, and T. Hakulinen. 1999. Risk of colorectal and other gastro-intestinal cancers after exposure to nitrate, nitrite and N-nitroso compounds: A follow-up study. Int. J. Cancer 80:852-856.

Kuwano, K., N. Tanaka, T. Shimizu, K. Nagatoshi, S. Nou, and K. Sonomoto. 2005. Dual antibacterial mechanisms of nisin $\mathrm{Z}$ against gram-positive and gram-negative bacteria. Int. J. Antimicrob. Agents 26:396-402.

Kuwata, H., T. Yip, M. Tomita, and T. W. Hutchens. 1998a. Direct evidence of the generation in human stomach of an antimicrobial peptide domain (lactoferricin) from ingested lactoferrin. Biochim. Biophys. Acta 1429:129-141.

Kuwata, H., T. Yip, K. Yamauchi, S. Teraguchi, H. Hayasawa, M. Tomita, and T. W. Hutchens. 1998b. The survival of ingested lactoferrin in the gastrointestinal tract of adult mice. Biochem. J. 334:321-323.
Larrea, M. T., I. Gómez-Pinilla, and J. C. Farinas. 1997. Microwaveassisted acid disolution of sintered advanced ceramics for inductively coupled plasma atomic emission spectrometry. J. Anal. At. Spectrom. 12:1323-1332.

Lönnerdal, B. 2003. Nutritional and physiological significance of human milk proteins. Am. J. Clin. Nutr. 77:1437S-1443S.

López-Expósito, I., J. A. Gómez-Ruiz, L. Amigo, and I. Recio. 2006a. Identification of antibacterial peptides from bovine $\alpha_{\mathrm{s} 2}$-casein. Int. Dairy J. 16:1072-1080.

López-Expósito, I., F. Minervini, L. Amigo, and I. Recio. 2006b. Identification of antibacterial peptides from bovine $\kappa$-casein. J. Food Prot. 69:2992-2997.

López-Expósito, I., and I. Recio. 2006. Antibacterial activity of peptides and folding variants from milk proteins. Int. Dairy J. 16:12941305.

Mansour, M., and J. B. Millière. 2001. An inhibitory synergistic effect of a nisin-monolaurin combination on Bacillus sp. vegetative cells in milk. Food Microbiol. 18:87-94.

McCann, D., A. Barrett, A. Cooper, D. Crumpler, L. Dalen, K. Grimshaw, E. Kitchen, K. Lok, L. Porteous, E. Prince, E. Sonuga-Barke, J. O. Warner, and J. Stevenson. Food additives and hyperactive behaviour in 3-year-old and 8/9-year-old children in the community: A randomised, double-blinded, placebo-controlled trial. Lancet. 370:1560-1567.

Pellegrini, A., A. J. Hülsmeier, P. Hunziker, and U. Thomas. 2004. Proteolytic fragments of ovalbumin display antimicrobial activity. Biochim. Biophys. Acta 1672:76-85.

Pol, I. E., and J. Smid. 2000. Combined action of nisin and carvacrol on Bacillus cereus and Listeria monocytogenes. Lett. Appl. Microbiol. 29:166-170.

Recio, I., and S. Visser. 1999a. Two ion-exchange chromatographic methods for the isolation of antibacterial peptides from lactoferrin. In situ enzymatic hydrolysis on an ion-exchange membrane. J. Chromatogr. A. 831:191-201.

Recio, I., and S. Visser. 1999b. Identification of two distinct antibacterial domains within the sequence of bovine $\alpha_{\mathrm{s} 2}$-casein. Biochim. Biophys. Acta 1428:314-326.

Roberts, C. M., and D. G. Hoover. 1996. Sensitivity of Bacillus coagulans spores to combinations of high hydrostatic pressure, heat, acidity and nisin. J. Appl. Microbiol. 81:363-368.

Schnurer, J., and J. Magnusson. 2005. Antifungal lactic acid bacteria as biopreservatives. Trends Food Sci. Technol. 16:70-78.

Sherman, M. P., S. H. Bennett, F. F. Hwang, and C. Yu. 2004. Neonatal small bowel epithelia: Enhancing anti-bacterial defense with lactoferrin and Lactobacillus GG. Biometals 17:285-289.

Singh, B., M. B. Falahee, and M. R. Adams. 2001. Synergistic inhibition of Listeria monocytogenes by nisin and garlic extract. Food Microbiol. 18:133-139.

Spik, G., B. Brunet, C. Mazurierdehaine, G. Fontaine, and J. Montreuil. 1982. Characterization and properties of the human and bovine lactotransferrins extracted from the feces of newborn-infants. Acta Paediatr. Scand. 71:979-985.

Stevens, K. A., B. W. Sheldon, N. A. Klapes, and T. R. Klaenhammer. 1991. Nisin treatment for inactivation of Salmonella species and other gram-negative bacteria. Appl. Environ. Microbiol. 57:3613-3615.

Taylor, S., J. Brock, C. Kruger, T. Berner, and M. Murphy. 2004. Safety determination for the use of bovine milk-derived lactoferrin as a component of an antimicrobial beef carcass spray. Regul. Toxicol. Pharmacol. 39:12-24.

Valenti, P., and G. Antonini. 2005. Lactoferrin: An important host defence against microbial and viral attack. Cell. Mol. Life Sci. 62:2576-2587.

Ward, P. P., and O. M. Conneely. 2004. Lactoferrin: Role in iron homeostasis and host defense against microbial infection. Biometals 17:203-208.

Zapico, P., M. Medina, P. Gaya, and M. Nuñez. 1998. Synergistic effect of nisin and the lactoperoxidase system on Listeria monocytogenes in skim milk. Int. J. Food Microbiol. 40:35-42. 